EMILIA WIECZOREK

ORCID 0000-0002-5523-1506

Uniwersytet im. Adama Mickiewicza

w Poznaniu

\title{
ZACHOWANIA TRUDNE I PROBLEMOWE MEODZIEŻY \\ Z NIEPEŁNOSPRAWNOŚCIĄ INTELEKTUALNĄ \\ W STOPNIU UMIARKOWANYM \\ I ZNACZNYM
}

\begin{abstract}
Wieczorek Emilia, Zachowania trudne i problemowe młodzieży z niepetnosprawnościa intelektualna w stopniu umiarkowanym i znacznym [Difficult and Problem Behaviors of Young People with Intellectual Disabilities to a Moderate and Significant Degree]. Studia Edukacyjne nr 55, 2019, Poznań 2019, pp. 271-282. Adam Mickiewicz University Press. ISSN 1233-6688. DOI: 10.14746/se.2019.55.16

The article deals with difficult and problem behaviors of young people with moderate and severe intellectual disabilities. For an accurate presentation of the specificity of functioning of a person with intellectual disability, the article presents functioning in particular developmental spheres. The argumentation gathered was confirmed by the results of our own research - IDI in-depth interviews
\end{abstract}

Key words: disability, intellectual disability, youth, difficult behavior, care problems, educational problems

\section{Ustalenia terminologiczne}

Prezentowana $\mathrm{w}$ niniejszej publikacji tematyka wymaga zdefiniowania i przyjęcia na gruncie literatury przedmiotu określeń, które są elementami składowymi niniejszej rozprawy. Należą do nich: faza młodzieńcza, niepełnosprawność intelektualna. Termin pierwszy wymaga ogólnego wskazania koncepcji K. Mannheima, który zakładał, iż 
pokolenia nie są jedynie kategoriami biologicznymi ustalanymi na podstawie kryterium wieku, ale są rezultatem procesów społecznych i historycznych. To pokolenia decydują o kształcie całego społeczeństwa ${ }^{1}$.

Literatura przedmiotu bogata w różnorodne definicje pożądanej fazy rozwojowej człowieka pozwala na przyjęcie wiodącej definicji, że młodzież to

jednostki znajdujące się $\mathrm{w}$ instytucjonalizowanym stanie przejściowym między dzieciństwem a dorosłością, w trakcie którego określone zostają ostateczne ramy tożsamości człowieka².

Drugim wskazaniem terminologicznym jest zjawisko niepełnosprawności intelektualnej, które przez lata obarczone było dużą ilością mitów i stereotypów. Sformułowanie niepełnosprawność intelektualna jest terminem stosunkowo nowym. Nazwa została wprowadzona z wielu powodów. Niewątpliwie jednym z nich były trendy występujące w pedagogice specjalnej oraz psychologii. Działanie takie miało na celu odejście od nazewnictwa stygmatyzującego ${ }^{3}$. Obecnie panujący trend $\mathrm{w}$ obrębie pedagogiki specjalnej zaowocował posługiwaniem się trzema najbardziej znanymi definicjami i klasyfikacjami. Należą do nich: definicja opracowana przez Amerykańskie Stowarzyszenie Niepełnosprawności Intelektualnej i Rozwojowej - AAIDD (American Association on Intellectual and Developmental Disabililities), definicja Amerykańskiego Towarzystwa Psychiatryczno-Diagnostycznego - DSM (Diagnistic and Statistic Manual of Mental Discorders) oraz definicja przedstawiona w Międzynarodowej Klasyfikacji Uszkodzeń Niepełnosprawności i Upośledzeń - ICD- $10^{4}$ (International Statistical Classification of Diseases and Related Health Problems). Ostatnią wskazaną klasyfikację przyjęto jako wiodącą na gruncie obecnych tu rozważań, która wskazuje, że

upośledzenie ujmowane jest jako zahamowanie lub niepełny rozwój umysłowy, wyrażający się przede wszystkim w upośledzeniu umiejętności, które ujawniają się w okresie rozwojowym i stanowią o ogólnym poziomie inteligencji, tzn. zdolności poznawczych, mowy, motorycznych i umiejętności społecznych. Może występować samodzielnie lub z innymi zaburzeniami psychicznymi lub fizycznymi. Oznacza to, iż osoby z niepełnosprawnością intelektualną charakteryzują się nieprawidłowo rozwiniętymi umiejętnościami i predyspozycjami. Występują u nich zaburzenia niepozwalające na prawidłowy przebieg procesów poznawczych, komunikacji, motoryki oraz występują nieprawidłowości w funkcjonowaniu społecznym ${ }^{5}$.

${ }^{1}$ T. Prauzner, Wptyw nowoczesnych mass mediów na osobowość człowieka, Edukacja - Technika - Informatyka, 2010, 7, s. 46-47.

${ }^{2}$ E.H. Erikson, Identifikation und Identität, [w:] Socjologiczne teorie młodzieży, wprowadzenie, red. H.M. Griese, Kraków 1996, s. 70.

${ }^{3}$ J. Wyczesany, Pedagogika upośledzonych umystowo, Kraków 2005, s. 18.

${ }^{4}$ R.L. Schalok, S.A. Borhwick-Duffy, R. Luckasson i in., Intellectual Disability. Definition, Classification and Systems of Supports. The AAIDD Ad Hoc Committee on Terminology and Classiffication, 11th Edition, Washington 2010, s. 276.

${ }^{5}$ S. Pużyński, J. Wciórka, Klasyfikacja zaburzeń psychicznych i zaburzeń zachowania w ICD-10, Warszawa 1998, s. 128. 


\section{Analiza funkcjonowania w poszczególnych sferach rozwoju człowieka}

Na potrzeby niniejszych rozważań w kontekście problemów opiekuńczo-wychowawczych młodzieży z niepełnosprawnością intelektualną w stopniu umiarkowanym i znacznym przedstawiona zostanie analiza specyfiki funkcjonowania w sferze społeczno-emocjonalnej, poznawczej oraz motorycznej.

\section{Specyfika funkcjonowania w sferze społeczno-emocjonalnej}

Rozwój społeczny jest jednym ze składników całościowego rozwoju psychofizycznego. Należy zwrócić uwagęiż:

Stosunki jednostki z otoczeniem zależą od zdolności rozumienia sytuacji występujących we współżyciu społecznym, od zdolności zapamiętywania, wyobrażania sobie oraz przewidywania skutków własnego działania ${ }^{6}$.

Biorąc pod uwagę, iż mowa tutaj o osobach z niepełnosprawnością intelektualną, należy pamiętać o wielorakich zaburzeniach czynności. Funkcjonowanie społeczne charakteryzuje się spostrzeganiem na poziomie egocentrycznym i ograniczonym rozumieniem sytuacji społecznych. Duże znaczenie odgrywa doświadczenie. Czynności dotyczące samoobsługi są bardzo zróżnicowane. Na uwagę zasługuje fakt, iż odpowiednie oddziaływania dają możliwość podejmowania współpracy, a także realizacji podstawowych zachowań prospołecznych, które warunkowane są cyklicznie powtarzającymi się czynnościami .

Rozwój społeczny młodzieży $\mathrm{z}$ niepełnosprawnością intelektualną $\mathrm{w}$ stopniu umiarkowanym pozostaje $\mathrm{w}$ związku $\mathrm{z}$ ich ogólnym rozwojem. Zauważalna jest bardzo duża potrzeba kontaktów społecznych oraz jasnych komunikatów werbalnych i pozawerbalnych, dających poczucie bezpieczeństwa, miłości i przynależności. Osoby z niepełnosprawnością intelektualną podejmują interakcje na miarę swoich możliwości. Jednak należy wskazać na dużą zmienność cech osobowości: od cech pożądanych, właściwych do cech niewłaściwych, społecznie nieakceptowanych. Osoby z niepełnosprawnością intelektualną $\mathrm{w}$ stopniu umiarkowanym $\mathrm{w}$ większości przypadków są samodzielne w prostych czynnościach samoobsługowych i z powodzeniem mogą wykonywać wyuczone oraz utrwalone czynności związane z życiem domowym. Prawidłowo rozumieją proste sytuacje wynikające z życia społecznego i na ogół przedstawiają swoje potrzeby. Potrafią także porozumiewać się oraz podejmować współpracę z innymi osobami ${ }^{8}$. Mowa tych osób jest jednak

\footnotetext{
${ }^{6}$ R. Kościelak, Psychologiczne podstawy rewalidacji upośledzonych umystowo, Warszawa 1989, S. 56.

7 B. Szychowiak, Pedagogika osób z niepetnosprawnościa ruchowa, [w:] Pedagogika specjalna, red. W. Dykcik, Poznań 2001, s. 43.

${ }^{8}$ J. Lausch-Żuk, Dzieci z głębsza niepetnosprawnościa intelektualna, [w:] Dziecko niepetnosprawne w rodzinie, red. I. Obuchowska, Warszawa 1989, s. 132.
} 
agramatyczna i niepoprawna, bardzo często bełkotliwa. Język mówiony opanowany w bardzo prostej formie, dysponuje ubogim zasobem słownictwa?

Specyfika funkcjonowania społeczno-emocjonalnego młodzieży z niepełnosprawnością intelektualną $\mathrm{w}$ stopniu znacznym rożni się od przypadku opisanego wyżej. Istnieją jednak pewne cechy wspólne, jak na przykład potrzeba komunikatów zapewniających poczucie miłości i bezpieczeństwa, które muszą być o wiele łatwiejsze w przekazie i zrozumieniu. Rozwój społeczno-emocjonalny młodzieży z niepełnosprawnością intelektualną w stopniu znacznym jest mocno zaburzony; osoby te potrafią jednak zaspokajać samodzielnie swoje potrzeby fizjologiczne oraz wykonywać proste czynności samoobsługowe, jak na przykład ubieranie się, czy przygotowanie prostego posiłku. Występuje poprawność rozumienia prostych sytuacji życia społecznego i zdolność porozumiewania się w prostych sprawach ${ }^{10}$.

\section{Specyfika funkcjonowania w sferze poznawczej}

Osoby z niepełnosprawnością intelektualną w stopniu umiarkowanym i znacznym charakteryzują się poważnymi uszkodzeniami centralnego układu nerwowego. Należy pamiętać, że na funkcjonowanie poznawcze człowieka składają się: uwaga, spostrzeganie, pamięć, myślenie, wyobraźnia i mowa. Pierwszy z elementów, czyli uwaga jest mimowolna. Jednak istnieje możliwość wywołania dowolnej uwagi. U osób z niepełnosprawnością intelektualną w stopniu umiarkowanym i znacznym występują problemy z koncentracją, najczęściej w sytuacjach wykonywania czynności, które nie cieszą się ich zainteresowaniem. Wobec tego występuje konieczność podtrzymywania uwagi przez bodźce z zewnątrz. Charakterystyczne są trudności z przerzutnością uwagi oraz brak jej podzielności ${ }^{11}$. Spostrzeganie jest niedokładne, występują trudności w dostrzeganiu szczegółów, przebiega ono wolno - jest to konsekwencja osłabionej dynamiki procesów nerwowych. Podobnie wolniej przebiega porównywanie bodźców z wewnętrznym obrazem, co jest spowodowane trudnościami podczas skupiania uwagi na najistotniejszych punktach. Występują trudności rozróżniania elementów szczegółowych, zauważania różnic w podobnych przedmiotach. Spostrzeganie cechuje się powierzchownością oraz nieprawidłową analizą i syntezą ${ }^{12}$. Pamięć jest mechaniczna, epizodyczna i proceduralna, nawiązuje do najprostszych czynności manualnych. Ponadto, jest krótkotrwała, znacznie ograniczona - zwłaszcza pamięć świeża. Występują skłonności do

\footnotetext{
9 J. Wyczesany, Pedagogika upośledzonych umysłowo, s. 38.

10 L. Lausch-Żuk, Dzieci z głębszą niepetnosprawnościa intelektualna, s. 134.

11 B. Szychowiak, Pedagogika osób z niepetnosprawnością ruchowa, s. 50.

12 Tamże, s. 53.
} 
konfabulacji1 ${ }^{13}$. Myślenie można określić jako konkretne na poziomie konkretnych wyobrażeń. Organizację informacji cechuje poziom polikonkretny. Zakodowane o świecie informacje są zapamiętywane głównie poprzez spostrzeganie i wyobrażenia. Występują trudności w kształtowaniu stałego pojęcia przedmiotu, zwłaszcza w niepełnosprawności znacznej. Dochodzi do procesu tworzenia i wykorzystywania pojęć, jednak bardzo często brakuje umiejętności definiowania. Umiejętność ta może być ukierunkowana na definiowanie ze względu na użytek, a w sytuacji niepełnosprawności umiarkowanej dodatkowo jeszcze na cechy. Antycypacja jest niewykształcona. Klasyfikacja elementów przebiega bardzo prosto - odbywa się na zasadzie łączenia w pary lub tworzenia kolekcji. Myślenie cechuje się trudnościami w wyodrębnianiu poszczególnych elementów czy własności przedmiotów. Porównywanie odbywa się jedynie ze względu na cechy zmysłowe. Często występują błędy hipergeneralizacji oraz hipogeneralizacji, niewykształcona umiejętność myślenia abstrakcyjnego, planowania, czy poszukiwania związków przyczynowo-skutkowych ${ }^{14}$.

\section{Specyfika funkcjonowania w sferze motorycznej}

Sprawność motoryczna u osób z niepełnosprawnością intelektualną jest opóźniona w stosunku do ich zdrowych rówieśników. Zauważono tendencję, że im głębszy poziom niepełnosprawności intelektualnej, tym bardziej opóźniony rozwój ruchowy. Osoby z niepełnosprawnością intelektualną w stopniu znacznym i umiarkowanych charakteryzują się słabą koordynacją ruchową ${ }^{15}$.

Zachowania trudne i problemowe. Specyfika funkcjonowania młodzieży z niepełnosprawnością intelektualną jest tematem wielu rozważań zarówno empirycznych, jak i teoretycznych. Najczęstszym sposobem badania funkcjonowania osób z niepełnosprawnością intelektualną jest porównanie ich funkcjonowania z funkcjonowaniem osób w normie intelektualnej. Na tle tak opracowanych badań porównawczych wskazuje się na różnice i koncentruje na odmiennościach ${ }^{16}$.

Istotnym zagadnieniem dla poruszanego tematu są zachowania trudne i problemowe, które powodują szereg kłopotów opiekuńczych i wychowawczych w poszczególnych sferach rozwojowych młodego człowieka. Zachowania problemowe, o których mowa, mogą być różnorodne i sprawiać trudności jednostce, osobie z nią współpracującej, czy też innym otaczającym ją

\footnotetext{
13 Tamże, s. 57.

14 Tamże, s. 59.

${ }^{15} \mathrm{~J}$. Wyczesany, Pedagogika upośledzonych umysłowo, s. 38-39.

${ }^{16}$ B. Cytowska, Dorośli z niepetnosprawnościa intelektualna w labiryntach codzienności. Analiza badań - krytyka podejść - propozycje rozwiąań, Torun 2011, s. 17-18.
} 
ludziom ${ }^{17}$. Wszelkie zachowania destrukcyjne u młodzieży z niepełnosprawnością intelektualną w bardzo dużym stopniu objawiają się agresją, która jest ukierunkowana w stronę samej jednostki z niepełnosprawnością (autoagresja) lub zachowań agresywnych skierowanych wobec innych jednostek. Należy zaznaczyć, iż wszelkie działania o charakterze agresywnym wpływają znacznie na funkcje poznawcze i społeczne. Na uwagę zasługuje fakt, iż uwarunkowania tych problemów nie są ściśle biologiczne. Co więcej, istnieje teoria, że mogą to być zachowania wyuczone ${ }^{18}$. Istotną rolę $\mathrm{w}$ podejmowaniu zachowań autoagresywnych odgrywa otoczenie oraz interakcje zachodzące w społeczeństwie. Można zauważyć, iż postawy społeczne charakteryzujące się dużą ochroną, nadmiernym wyręczaniem czy współczuciem budzą $\mathrm{w}$ jednostce $\mathrm{z}$ niepełnosprawnością emocje negatywne. To właśnie one powodują agresję ${ }^{19}$. Podobnie jak w innych przypadkach zaburzeń zachowania, tak i tutaj zależą one od stopnia niepełnosprawności intelektualnej. Badacze zwracają także uwagę, iż wszelkie zachowania autoagresywne stanowią wyuczoną reakcję instrumentalną. Są one także możliwymi sposobami stymulacji zmysłowej i efektem bólu, złej temperatury ciała, hałasu, czy nawet przebywania $\mathrm{w}$ tłoku ${ }^{20}$.

Zachowaniami, które nie zostały uznane na gruncie literatury przedmiotu jako zachowania problemowe, a jednak powodują znaczne problemy w przebiegu procesu rehabilitacji osób z niepełnosprawnością intelektualną, są depresja i zachowania lękowe. Diagnoza osób z niepełnosprawnością intelektualną przysparza wielu problemów, a podstawowy dotyczy zróżnicowania umiejętności poznawczych oraz społecznych. Objawy depresji zależne są od stopnia niepełnosprawności. Należy pamiętać, iż w wielu przypadkach różnią się od objawów dotyczących osób w normie intelektualnej ${ }^{21}$. Do charakterystycznych objawów zaliczyć można: złe samopoczucie, afekt depresyjny oraz duże problemy ze snem. Są one w ogóle niezależne od normy intelektualnej. Natomiast objawy charakterystyczne, zależne od stopnia niepełnosprawności prezentują się nieco inaczej. Analizując depresję oraz jej objawy u osób z niepełnosprawnością intelektualną w stopniu umiarkowanym i znacznym, należy zwrócić uwagę na objawy powodujące zachowania problemowe: drażliwość, pobudzenie psychoruchowe, obniżenie, a nawet utrata zachowań adaptacyjnych. Wraz z tymi objawami mogą pojawić się zachowania agresywne, krzyk, czy nawet samookaleczanie. Jeśli natomiast przyjrzymy się niepełnosprawności intelektualnej w stopniu umiarkowanym, to depresja ce-

${ }^{17}$ I. Obuchowska, Dziecko niepetnosprawne w rodzinie, Warszawa 1995, s. 76.

${ }_{18}$ M. Orzeł, Zaburzenia psychiczne i zaburzenia zachowania u osób upośledzonych umystowo, Zeszyty Naukowe WSSP 2013, 16, s. 92.

${ }_{19}$ Tamże.

${ }^{20}$ Tamże, s. 93.

${ }^{21}$ Tamże, s. 89. 
chuje się u tych jednostek różnorodnymi działaniami autoagresywnymi oraz wycofaniem z życia społecznego ${ }^{22}$.

Zaburzenia lękowe występują bardzo często u osób z niepełnosprawnością intelektualną. Spektrum objawów jest tutaj bardzo rozległe, w związku czym zaburzenia lękowe są często niezdiagnozowane. Do najbardziej charakterystycznych ich objawów możemy zaliczyć zachowania agresywne oraz autoagresywne, agitacyjne i kompulsywne. Często spotykanym przejawem jest także krzyk lub płacz, bezsenność, znacznie większa aktywność oraz emocjonalna labilnośćc ${ }^{23}$. Częstymi przypadłościami przy zaburzeniach lękowych, które mogą być przejawem stresu pourazowego, są ataki paniki, zaburzenia obsesyjno-kompulsywne, a także różnorodne fobie. Należy pamiętać, iż u osób niepełnosprawnych intelektualnie są one często determinowane środowiskiem. Osoby te muszą nieustannie zmierzać się z różnymi oczekiwaniami i często negatywną oceną społeczeństwa. Jeśli dodamy do tego ograniczone umiejętności postrzegania i właściwej analizy, wówczas nie powinny nas dziwić zaburzenia lękowe ${ }^{24}$.

\section{Badania własne}

Na potrzeby niniejszego artykułu przeprowadzono badania ${ }^{25}$, których celem było zdefiniowanie zachowań trudnych i problemowych młodzieży w kontekście problemów opiekuńczo-wychowawczych. Dokonując analizy wyników tych badań, będę kolejno charakteryzowała wskazane przez respondentów trudności w poszczególnych sferach funkcjonowania.

\section{Funkcjonowanie społeczno-emocjonalne}

Analizując odpowiedzi respondentów na temat trudności występujących $\mathrm{w}$ funkcjonowaniu społeczno-emocjonalnym, na szczególną uwagę zasługuje fakt, iż zdecydowana większość respondentów wskazywała na „niski iloraz inteligencji”. Dużym, wielokrotnie ukazanym problemem był znacznie ograniczony zasób słownictwa. Podkreślano konieczność pracy

${ }^{22}$ Tamże, s. 90.

${ }^{23}$ Tamże.

${ }^{24}$ Tamże, s. 92.

${ }^{25}$ Badania zostały przeprowadzone wśród osób pracujących z osobami niepełnosprawnymi intelektualnie. W wielu przypadkach są to asystenci oraz wolontariusze, jednak wśród respondentów znalazły się osoby prowadzące prywatną praktykę psychologiczną, terapeutyczną, czy pedagogiczną. Uważam, iż obcując na co dzień z osobami niepełnosprawnymi intelektualnie zgromadzili różnorodne doświadczenia z zakresu ich funkcjonowania oraz trudności pojawiające się na rożnych płaszczyznach życia. Badania prowadzone przeze mnie miały na celu zdiagnozowanie problemów opiekuńczo-wychowawczych na gruncie poszczególnych sfer funkcjonowania. 
nad podstawowym słownikiem komunikacji. Zwrócono także uwagę na zagrożenia płynące z braku umiejętności postrzegania związków przyczynowo-skutkowych. Analiza wszystkich wypowiedzi wskazuje, iż rozwój społeczno-emocjonalny młodzieży z niepełnosprawnością intelektualną w stopniu umiarkowanym i znacznym jest zagadnieniem skomplikowanym i zindywidualizowanym. Osoby ze wskazaną niepełnosprawnością często przekraczają granicę bliskości w relacjach społecznych, bywają nachalne i bardzo absorbują swoją osobą. Często ich zachowania są nieadekwatne do bodźca. Istotną trudnością jest:

(...) brak uświadomienia pełnosprawnych ludzi o problemach wynikających z niepetnosprawności intelektualnej tego stopnia. Powoduje to odrzucenie i zmarginalizowanie osób z niepetnosprawnością intelektualną. Ma to bardzo negatywny wptyw na motywacje tych osób podczas dalszego procesu rehabilitacji. [R8]

Nieprawidłowości $w$ funkcjonowaniu społeczno-emocjonalnym powodują silny emocjonalny związek z nauczycielem, rehabilitantem, asystentem, opiekunem i tak dalej. Jest to zjawisko bardzo problemowe, ponieważ może prowadzić do wielu nieporozumien, rozczarowań, a w konsekwencji do niechęci realizowania procesów rozwojowych z daną osobą (mowa tutaj o niechęci ze strony osoby z niepełnosprawnością ze względu na poczucie odrzucenia).

\section{Samoobsługa}

Osoby badane zwróciły uwagę na brak umiejętności wykonywania podstawowych czynności samoobsługowych. Odwoływano się także do zagrożeń płynących z braku umiejętności przewidywania własnych zachowań. Respondenci zwracali uwagę na fakt, iż ogromny wpływ na trudności w tej płaszczyźnie ma zupełnie rozbudowana emocjonalność, nieumiejętność koncentracji uwagi. Im większy stopień trudności wykonywanego zadania, tym większe zagrożenie, iż może mieć ono negatywny skutek dla osoby z niepełnosprawnością, a także dla innych osób. Powoduje to konieczność ciągłej obecności asystenta, może prowadzić do rozproszenia uwagi i dekoncentracji. Obniża zdolności i umiejętności wykonywania wielu czynności w przebiegu procesu rehabilitacji. Opanowanie umiejętności samoobsługowych uznane było przez większość respondentów jako jeden z rodzajów rehabilitacji. Zwracano uwagę na trudności, jakie tutaj występują:

Słaba koordynacja ruchowa oraz nieptynność ruchów powoduja duże utrudnienia w wykonywaniu czynności samoobstugowych. [R7]

Zwracano także uwagę na konieczność obecności opiekuna/asystenta podczas wykonywania prostych czynności samoobsługowych. 
Asystent osoby z niepetnosprawnością intelektualna musi pozostawać przy niej caty czas. To ciagłe sprawdzanie temperatury wody, postugiwania sie przyrzadami kuchennymi czy przyborami szkolnymi. Nawet w sytuacji kiedy pozornie umiejętność ta zostanie opanowana, nie można pozostawić takich działań bez kontroli. Zupetnie inaczej rozbudowana emocjonalność, brak koncentracji uwagi i analizy związków przyczynowo-skutkowych może zaowocować urazem. Dlatego należy pamiętać, iż koncentrujemy się na nauce używania różnego typu przedmiotów czy samodzielnego korzystania np. z toalety. Jednak zawsze pozostaje to pod nadzorem. [R1]

\section{Komunikacja}

Wszystkie odpowiedzi respondentów wskazują na ograniczony zasób słownictwa, a co za tym idzie - budowanie podstaw komunikacji. Bardzo często ogromna wada wymowy, złe artykułowanie słów powoduje, że osoba pracująca z niepełnosprawnymi intelektualnie musi nauczyć się swoistego sposobu komunikacji alternatywnej, a respondenci wskazywali na jej zalety:

Często komunikacja werbalna jest problematyczna. Osoby z niepetnosprawnościa intelektualna w stopniu umiarkowanym i znacznym znaja swoje potrzeby, jednak dochodzi do blokady i nieumiejętności przekazu. Dobrym rozwiązaniem jest właśnie komunikacja alternatywna. Przykładem takiej komunikacji jest PECS. Łatwa i przystępna jej forma ułatwia znacznie proces komunikacji. [R4]

\section{$\mathrm{Lub}$}

Problemy z prawidłowa komunikacja sa $i$ zawsze będa charakterystyczna cecha osób z niepetnosprawnościa. Jednak istnieje możliwość komunikacji alternatywnej. Przykładem sa grupy metod w komunikacji AAC, gdzie funkcjonuje system znaków manualnych, graficznych i przestrzenno-dotykowych, znacznie ułatwiajacych proces komunikowania się. [R6]

\section{Funkcjonowanie poznawcze}

Szczególną uwagę osoby badane zwróciły na: ograniczone zdolności komunikacyjne, brak wielopłaszczyznowego postrzegania, nieumiejętność przewidywania skutków i brak myślenia abstrakcyjnego. Osobliwą trudnością jest tutaj brak syntezy i analizy związków przyczynowo-skutkowych różnorodnych zjawisk zachodzących w otaczającym świecie. Do trudności wynikających z nieprawidłowego funkcjonowania poznawczego zaliczamy konieczność indywidualizowania środków dydaktycznych i terapeutycznych. Wskazano, iż:

asystent osoby z niepetnosprawnościa intelektualna musi być nastawiony na poszukiwanie nowych rozwiązań. Konieczność dostosowania metod do funkcjonowania psychiki podopiecznego jest dużym wyzwaniem. Trzeba stale pobudzać motywacje $i$ zachęcać do podejmowania kolejnych wyzwań. Należy jednak pamiętać o dostosowaniu skali trudności zadań, z którymi jednostka się zmierza. [R11] 


\section{Funkcjonowanie motoryczne}

Potrzeby ruchowe człowieka z niepełnosprawnością intelektualną są kwestią bardzo zindywidualizowaną - to ogólny wniosek z analizy wypowiedzi osób badanych. Respondenci wskazywali, iż wiele osób nie przejawia chęci ponadpotrzebnego ruchu. Ma to też niewątpliwie związek z wieloma niepełnosprawnościami sprzężonymi, powodując ograniczenie procesu rehabilitacji nie tylko ruchowej. Często występuje konieczność dotarcia na zajęcia rehabilitacyjne i terapeutyczne, co niewątpliwie łączy się z koniecznością ruchu. Niechęć wywołana jego koniecznością ma zatem negatywny wydźwięk na całościowy przebieg procesu rehabilitacji. W odpowiedziach respondentów widać pewną sprzeczność. Jeden z nich marginalizuje rozwój motoryczny:

Rozwój motoryczny osób niepetnosprawnych intelektualnie nie będzie miał aż tak dużego znaczenia w przypadku rehabilitacji umystowej, może on się wiązać bardziej z brakiem skupienia czy rozkojarzeniem wynikających z potrzeb ruchowych człowieka. [R6]

Inny z kolei upatruje w nim pobudki do społecznego odrzucenia:

Bardzo często spotykamy się z reakcjami ruchowymi - takimi nadpobudliwymi. Bardzo często sa one teżźle odbierane i pojawiaja się na ich podstawie opinie stereotypowe na temat osób niepetnosprawnych intelektualnie. Są one bardzo krzywdzace i znacznie ograniczaja możliwość wspótuczestnictwa w życiu społecznym. [R11]

\section{Zachowania agresywne}

Stanowią one niezmiernie istotny problem w podejmowaniu działalności opiekuńczo-wychowawczej. Stwierdzenie to jest charakterystyczne dla wszystkich osób, które brały udział w badaniach. Nieodzownie zachowania agresywne łączą się z nieumiejętnym funkcjonowaniem społeczno-emocjonalnym. Źle zrozumiane intencje powodują narastające napięcie, które często kończy się zachowaniem agresywnym. Respondenci wielokrotnie zaznaczali, iż zachowanie agresywne jest istotnym czynnikiem w procesie wykluczenia społecznego. Ludzie zdrowi bojąc się reakcji ze strony osób z niepełnosprawnością intelektualną, często doprowadzają do ich izolacji. Jeden z respondentów przedstawił następującą sytuację:

(...) będąc kiedyś wychowawca podczas turnusu rehabilitacyjnego, miałam podopiecznego z przejawami zachowań agresywnych w bardzo nasilonym stadium. Chtopiec będacy pod moją opieka w bardzo odważny i nagminny sposób podejmowat próby nawiazania kontaktów społecznych. Kiedy ktoś nie reagowat, popadat w złość. Zdarzało się, że potrafit kogoś popchnać, uderzyć, oblać zupa itd. (...) co jeszcze bardziej potegowato odtracenie. [R2] 
Inny respondent wskazuje:

Zachowania agresywne sa przejawem nieprawidłowo funkcjonujacej sfery emocjonalnej. W istocie, poznanie wychowanka powoduje, iż jesteśmy w stanie przewidzieć okoliczności, które moga doprowadzić do takich zachowań i starać się je wyeliminować. [R8]

\section{Zachowanie autoagresywne}

Rozmowa z respondentami wykazała, iż zachowanie autoagresywne w przypadku osób z niepełnosprawnością intelektualną ma podłoże w braku rozumienia otaczającej ich rzeczywistości. Bardzo często nawet dobre intencje są źle odbierane. Również brak umiejętności sformułowania myśli w sposób klarowny dla otoczenia może powodować zachowania autoagresywne. Bardzo często po akcie autoagresji osoby wycofują się z grupy społecznej, w której funkcjonują. Trudności wynikające z zachowań autoagresywnych koncentrują się na konieczności zastosowania odpowiednich metod, aby pozytywnie wzmacniać zachowania pożądane.

\section{Masturbacja}

Temat ten był niechętnie poruszany przez moich respondentów. Zwrócili oni jednak uwagę, iż nawykowa masturbacja jest zjawiskiem bardzo negatywnym. Osoby z niepełnosprawnością intelektualną nie kontrolują tego typu zachowań, toteż może do nich dochodzić w miejscach publicznych. Jest to niezmiernie istotny problem, ponieważ przyczynia się również do izolacji i społecznego wykluczenia. Respondenci wskazywali, iż pracują nad problemem masturbacji swoich podopiecznych, jednak odmawiali szczegółowej odpowiedzi na to pytanie. Problem ten pojawiający się w procesie rehabilitacji był dla respondentów krępujący. Inne osoby badane zaprzeczały istnieniu tego zjawiska. Pytanie to spotkało się z dużą niechęcią i brakiem konkretnych odpowiedzi, mających tutaj znaczny wpływ na edukacyjną rzeczywistość.

\section{Konkluzja}

Zachowania trudne i problemowe młodzieży z niepełnosprawnością intelektualną powodują szereg kłopotów opiekuńczych i wychowawczych. W zależności od stopnia niepełnosprawności utrudniają, a często uniemożliwiają prawidłowe funkcjonowanie $\mathrm{w}$ obrębie poszczególnych sfer życiowych. Zaprezentowane badania wskazują, iż przedstawione na gruncie literatury zachowania trudne i problemowe są aktualnym zjawiskiem w różnorodnych obszarach życia jednostek $\mathrm{z}$ niepełnosprawnością intelektualną $\mathrm{w}$ stopniu umiarkowanym i znacznym oraz osób z nimi pracujących. 


\section{BIBLIOGRAFIA}

American Psychiatric Association, Diagnostic and Statistical Manual of Mental Disorders, Fifth Edition (DSM-5), United States 2013.

Cytowska B., Dorośli z niepetnosprawnościa intelektualna w labiryntach codzienności. Analiza badań - krytyka podejść - propozycje rozwiąań, Torun 2011.

Dega W., Wiktora Degi ortopedia i rehabilitacja, Poznań 2004.

Erikson E.H., Identifikation und Identität, [w:] Socjologiczne teorie młodzieży, wprowadzenie, red. H.M. Griese, Kraków 1996.

Głodkowska J., Założenia i kontekst procesu rehabilitacji osób z niepetnosprawnościa intelektualna, [w:] Osobowość, samorealizacja, odpowiedzialność, bezpieczeństwo, autonomia. Teoria, empiria i praktyka w rehabilitacji osób z niepetnosprawnościa umysłowa od dzieciństwa do póżnej dorosłości, red. J. Głodkowska, A. Giryński, Warszawa 2004.

Hulek A., Człowiek niepetnosprawny w społeczeństwie, Materiały II Kongresu TWK, Warszawa 1986.

Kościelak R., Psychologiczne podstawy rewalidacji upośledzonych umystowo, Warszawa 1989.

Lausch-Żuk J., Dzieci z głębsza niepetnosprawnością intelektualna [w:] Dziecko niepetnosprawne w rodzinie, red. I. Obuchowska, Warszawa 1989.

Lausch-Żuk J., Pedagogika osób z umiarkowanym, znacznym i głębokim upośledzeniem umystowym, [w:] Pedagogika specjalna, red. W. Dykcik, Poznań 2001.

Obuchowska I., Dziecko niepetnosprawne w rodzinie, Warszawa 1995.

Obuchowska I., Osoby niepetnosprawne: diagnoza dla rozwoju, [w:] Diagnoza dla osób niepetnosprawnych, red. D. Lotz, K. Wenta, W. Zendler, Szczecin 2006.

Orzeł M., Zaburzenia psychiczne i zaburzenia zachowania u osób upośledzonych umysłowo, Zeszyty Naukowe WSSP, 2013, 16.

Prauzner T., Wptyw nowoczesnych mass mediów na osobowość człowieka, Edukacja - Technika - Informatyka, 2010, 7.

Pużyński S., Wciórka J., Klasyfikacja zaburzeń psychicznych i zaburzeń zachowania w ICD-10, Warszawa 1998.

Schalok R.L., Borhwick-Duffy S.A., Luckasson R. i in., Intellectual Disability. Definition, Classification and Systems of Supports. The AAIDD Ad Hoc Committee on Terminology and Classiffication, 11th Edition, Washington 2010.

Szychowiak B., Pedagogika osób z niepetnosprawnością ruchowa, [w:] Pedagogika specjalna, red. W. Dykcik, Poznań 2001.

Trempała J., Psychologia rozwoju człowieka. Podręcznik akademicki, Warszawa 2011.

Wyczesany J., Pedagogika upośledzonych umystowo, Kraków 2005. 